\title{
Bilişsel ve Duygusal Düzenlemenin Sınav Kaygısına Olan Etkisinde Psikolojik Dayanıklılığın Aracılık Rolü
}

\section{The Mediation Role of Resilience in the Effect of Cognitive and Affective Regulation on Test Anxiety}

\author{
Tarık TOTAN 1, Özge ÖZGÜL², Ezgi TOSUN ${ }^{3}$
}

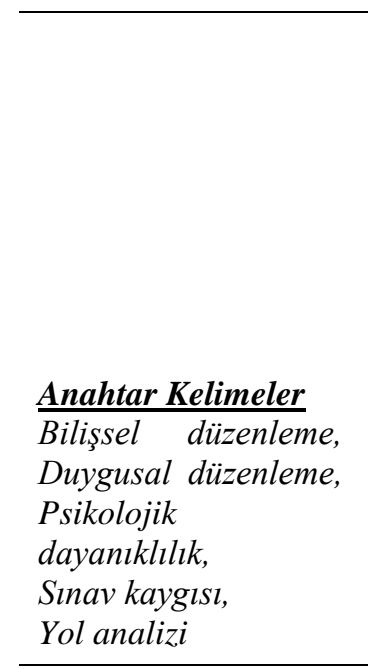

\begin{abstract}
$\ddot{O}_{z e t}$
Sınav kaygısı, öğrencilerin akademik yaşamlarını olumsuz yönde etkileyen önemli bir sorundur. Akademik yaşamin yanı sıra sosyal ve duygusal yaşamı da olumsuz yönde etkileyen bu faktörü, farkll boyutlarıyla incelemek önleyici rehberlik için oldukça önemlidir. Bu araştırmada, bilişsel ve duygusal düzenlemenin sinav kaygısını azalttığl ve bu etkilere psikolojik dayanıklllı̆ıı aracılık rolünün bulunduğuna yönelik bir hipotez model test edilmiştir. Araştırmaya 252 'si kadın $(\% 68,65), 115$ 'i erkek $(\% 31,35)$ olmak üzere toplam 367 üniversite öğrencisi katılmıştır. Araştırmada Bilişsel ve Duygusal Düzenleme Ölçeği, Kıssa Psikolojik Dayanıklılık Ölçeği ve Westside Sınav Kaygısı Ölçeği kullanılmıştır. Araştırma bulgularına göre bilişsel ve duygusal düzenlemeyle psikolojik dayanıklılık arasında pozitif yönde ilişkiler bulunmaktadır. Bu üç değişkenin sınav kaygısıyla olan ilişkisi negatif yöndedir. Yapısal eşitlik modelinde yol analizi bulguları, bilişsel ve duygusal düzenlemenin psikolojik dayanıklılıkla pozitif yönde, psikolojik dayanıklılığın ise sınav kaygısıyla negatif yönde yollara sahip olduğunu göstermiştir. Bilişsel düzenleme ve sınav kaygısı arasında psikolojik dayanıklılık kısmi aracılık rolüne sahiptir. Duygusal düzenleme ve sinav kaygısı arasinda ise psikolojik dayanıklılık tam aracıdır. Sinav kaygısı, bilişsel düzenlemeden daha fazla etkilenmektedir. Bu sebeple de sınav kaygısını azaltmada bilişsel düzenlemeye dayalı önleyici rehberlik etkinlikleri daha kararlı sonuçlar verebilir

Abstract

Test anxiety is an important problem that negatively affects students in their academic lives. Also, this factor negatively affects students' social and emotional life as well as their academic life. For this reason, examining different dimensions of test anxiety is very important for preventive guidance. In this study, the hypothesis model that cognitive and emotional regulation reduces test anxiety and that resilience have mediating effect on these relationships was tested. A total of 367 university students participated in the study (female $n=252,68.65 \%$; male $n=115$ male, 31.35\%). The Cognitive and Affective Regulation Scale, the Brief Resilience Scale and the Westside Test Anxiety Scale were used for collect data. According to the findings of the research, there are positive relationships between cognitive regulation, emotional regulation, and resilience. The relationships between these three variables and test anxiety were negative. Path analysis findings in the structural equation model showed that cognitive and affective regulation had negative path with test anxiety and positive path with resilience. And resilience had negative path with test anxiety. Resilience between cognitive regulation and test anxiety has a partial mediating effect. Also, resilience between emotional regulation and test anxiety has a full mediating effect. Test anxiety is more affected by cognitive regulation. According of this reason, preventive guidance activities based on cognitive regulation in reducing test anxiety may give more stable results.
\end{abstract}

$\underline{\text { Key Word }}$ Cognitive regulation Affective regulation, Resilience, Test anxiety, Path analysis,

\begin{abstract}
Attf için:
Totan, T.; Özgül, Ö. \& Tosun, E. (2019). Bilişsel ve duygusal düzenlemenin sınav kaygısına For Citation olan etkisinde psikolojik dayanıklılığın aracılık rolü. Muğla Sıtkı Koçman Üniversitesi Eğitim Fakültesi [MSKU Journal of Education], 6(2), 98-108. DOI: 10.21666/muefd.605853
\end{abstract}

Received: 16.08.2019 $\quad$ Accepted: 08.10.2019 Published: 01.11.2019

\footnotetext{
${ }^{1}$ Aydın Adnan Menderes Üniversitesi, Eğitim Fakültesi, , tarik.totan@ adu.edu.tr ORCID 0000-0001-8859-3338

${ }^{2}$ Sinav Eğitim Kurumları, Okul Psikolojik Danıșmanı,ozgeozgul8@gmail.com ORCID 0000-0003-0031-060X

${ }^{3}$ Kanuni Sultan Süleyman İlkokulu, Okul Psikolojik Danışmanı, ezgitosuunn@gmail.com ORCID 0000-0002-8799-6175
} 
Günümüz eğitim hayatında sınavlar öğrenciler için akademik yükselmenin önemli bir parçası durumundadır. Bu nedenle öğrenciler erken yaşlarından itibaren sınavların getirdiği eğitsel hazırlanma yükünü taşımaya çalışmaktadır. Ancak, bu yük arttığında ya da sosyal, duygusal ve bilişsel istenmeyen başka faktörler sınavlara hazırlanma sorumluluğunu etkilemeye başladığında, öğrencilerin kaygı düzeyleri artmaktadır. Kaygı, bireyin yaşadığı bir duygu olarak iç dünyasından veya dış etmenlerden kaynaklanan tehlike unsurları ya da kişinin tehlike olarak algıladığı durumlar sonucu ortaya çıkar (Kurt, 2011). Plotnik (2009); tedirginlik, yüksek nabız ve kan basıncı gibi aşırı fizyolojik belirtilerin kaygının tipik özellikleri olduğunu ifade etmiştir. Bu olumsuz fizyolojik etkilerinin yanında orta düzeyde hissedilen kaygı bireyin olası tehlikeler karşısında duruma uyum sağlamasına, hazırlanmasına ve durumdan kaçınması için plan yapmasına yardımcı olur (Kring, Johnson, Davidson ve Neale, 2015). Aslında kaygı yaşamın doğal bir parçası olarak; hayatın tadına varmak, hayallerin peşinden gitmek, zihinsel olarak uyanık olmak ve hedeflere ulaşmak için yardımcı olabilecek itici güçlerden biri olaak değerlendirilmektedir (Peters Mayer, 2008). Ancak kaygının dozajı arttıkça birey için getirdiği olumsuzlukları da artış göstermektedir.

Eğitim alanında yapılan çalışmalar incelendiğinde kaygı kavramı birçok araştırmaya konu olan önemli bir değişkendir (Baltaş, 2002). Sınav kaygısı ise yirminci yüzyılın başından beri eğitim araştırmalarında yer almaktadır (Zeidner, 1998, Cassady ve Johnson, 2002). Başlarda sınav kaygısı; sınav sırasındaki pek çok boyutu içeren unsurun dikkate alındığ 1 tek boyutlu bir yapı şekilde ele alınırken, geçtiğimiz elli yılda bilişsel ve duygusal bileşenler daha fazla dikkate alınmaya başlanmıştır (Cassady ve Johnson, 2002). Zamanla, sınav kaygısı bireyin değerlendirilme korkusundan doğan yaşadığı tedirginlik duygusu olarak tanımlanmıştır (Erözkan, 2004). Sınav kaygısının yaygınlığı geniş örneklemler üzerinden incelendiğinde, sınav kaygısının giderek artma eğilimi gösterdiği ve ABD öğrencilerinin beşte birini etkileyen ciddi bir sorun olduğu rapor edilmiştir (Zeidner, 1998). Okullardaki temel kaygı kaynağının genellikle sınavlar olduğu görülmektedir. Bu değerlendirilme korkusu, değerlendiricinin öğrenci hakkında negatif yargı belirtme ihtimalinden kaynaklanmaktadır (Peters Mayer, 2008; Ormrod, 2015). Kurt'a göre (2011) sınav kaygısı fizyolojik, bilişsel ve davranışsal boyutları bulunan rahatsız edici bir duygudur. Sınav kaygısının hissedilen düzeyi bırakacağı etkinin de yönünü belirlemektedir. Düşük sınav kaygısına sahip bireylerin akademik başarılarının, yüksek sınav kaygısına sahip bireylerden ve sınav kaygısına sahip olmayan bireylerden daha yüksek olduğu tespit edilmiştir. Bu durum, düşük düzeyde sahip olunan sınav kaygısının akademik başarıya olumlu etkisinin olduğunu göstermektedir (Ormrod, 2015). Özetle, kaygının uç noktalarda yaşanması olumsuz etkiler bırakırken orta düzeyde yaşaması ise uyum sağlayıcı bir etkiye sahiptir (Kring, Johnson, Davidson ve Neale, 2015). Diğer bir ifadeyle sınav kaygısının asgari düzeyde yaşanması akademik başarıya olumlu katkı sağlamaktadır.

Kuramsal temelinde sınav kaygısı pek çok farklı arka plana sahiptir. Bunlar; Dürtü Modeli, Dezavantaj Modeli, Bilişsel Motivasyonel Model ve İşlemsel Model olarak sıralanabilir (Zeidner, 1998). Ancak, sınav kaygısı kuramsal temelinde ele alınırken ülkemizde genellikle kuruntu ve duygu olarak iki bileşende değerlendirildiği görülmektedir (Ergene, 2011; Kavakcı, Güler ve Çetinkaya, 2011; Güler ve Çakır, 2013). Kuruntu boyutu, bireyin sınava ilişkin bilişlerini içerir. Bu bilişler daha çok olumsuz yöndedir ve akılcı olmayan inançlardır. Duygu boyutu ise bireyin sınava karşılık duygusal tepkilerini içermektedir. Bireyin başarısızlık öngörüsü kuruntu boyutunu besler ve öğrencinin odak noktasının sınavdan ayrılmasına neden olur. Bunun sonucu olarak da öğrencilerin başarı oranın da düşüş gözlenir. Duygu boyutunun kuruntu boyutuna oranla başarıyı daha az yordadığı görülmüştür (Kurt, 2011). Ancak, sınav kaygısını açıklayan tek kuramsal yaklaşım bu değildir. Bilişsel Karışım Modeli (Cognitive Interference Model), yüksek düzeyde sınav kaygısı olan öğrencilerin sınav sırasında rekabet eden düşüncelerini bastıramadıkları için büyük ölçüde sınav sırasında yetersiz performans gösterdiğini ileri sürer (Cassady ve Johnson, 2002). Bu iki yaklaşımda sınav kaygısının bilişsel düzenlemeyle daha ilgili bir sorun olduğunu göstermektedir.

Öğrencilerin sınav kaygısı düzeyleri onların sosyal çevresindeki bireylerden etkilenen bir değişkendir. Sınav kaygısı ile ebeveyn tutumları arasındaki ilişkiyi inceleyen araştırmalara bakıldığında; demokratik aile tutumunun sınav kaygısını azalttığı (Kartalkıyı, 2016), otoriter ve koruyucu aile tutumlarının ise sınav kaygısını arttırdığı gözlenmektedir (Eker, 2016). Güvenli bağlanma sınav kaygısını anlamlı düzeyde yordamazken güvensiz bağlanma sınav kaygısını anlamlı düzeyde 
yordamaktadır (Ürgüp, 2017). Sadece aileyle ilgili değişkenler değil, okul temelinde ortaya çıkan bir dizi sosyal değişkende sınav kaygısının düzeyini arttırmaktadır. Örneğin, akademik başarısı üzerinde öğretmenlerinin tutumlarının olumsuz etkisinin olduğunu düşünen öğrencilerin sınav kaygısı düzeyleri daha yüksektir (Aydoğmuş, 2016). Derin ders çalışma yaklaşımındaki artış, sınav kaygısını ve sınav kaygısının fiziksel belirtilerini artmaktadır (Bükülmez, 2015). Diğer bir araştırma sonucunda göre okul tükenmişliği arttıkça, sınav kaygısı da artmaktadır (Demir, 2015). Başka bir bulgu da ise üniversite öğrencilerinin kinestetik öğrenme stili puanları arttıkça sınav kaygısı puanları azalmaktadır (Koç, 2014). Bu bulgular sınav kaygının sosyal çevreyle yakından ilişkisini ortaya koymaktadır. Ancak, sınav kaygısı sosyal çevre kadar öğrencinin psikolojik dayanıklılık düzeyleriyle de ilişkili bir değişkendir.

Pozitif psikolojinin önemli değişkenlerinden biri olan psikolojik dayanıklılık araştırmalarda genellikle dolaylı olarak sınav kaygısıyla incelenmiştir. Örneğin, Aydın (2017) psikolojik esneklik ve mükemmeliyetçiliğin sınav kaygısıyla pozitif yönde, bilişsel ayrışmanın ise sınav kaygısıyla negatif yönde etkilediğini rapor etmiştir. Benzer bir çalışmada, öğrencilerin yüksek olumlu mükemmeliyetçilik düzeyleri onların sınav kaygısı düzeylerini azaltmakta, yüksek olumsuz mükemmeliyetçilik düzeyleri ise sınav kaygısı düzeylerini arttırmaktadır (Hanımoğlu, 2010). Umut ve benlik saygısı değişkenleriyle de sınav kaygısının incelendiği araştırmalar bulunmaktadır. $\mathrm{Bu}$ araştırmalardan birinde öğrencilerin umutsuzluk düzeyi arttıkça sınav kaygısı düzeylerinin arttı̆̆ tespit edilmiştir (Serim, 2016). Bununla birlikte benlik saygısı yüksek bireylerin benlik saygısı düşük bireylere göre daha az sınav kaygısı yaşadıkları sonucuna ulaşıldığı da bulgulanmıştır (Turan-Başoğlu, 2007). Diğer bir çalışma da ise üst biliş ve pozitif psikolojik sermayenin sınav kaygısı ile olumsuz yönde ilişkili olduğuna ulaşılmıştır (Kahramanoğlu, 2018). Bu çalışmalar psikolojik dayanıklılığın sınav kaygısını azalttığına yönelik dolaylı açıklamalar olarak kabul edilebilir.

Ülkemizde sınav kaygısıyla ilgili çalışmalar geçtiğimiz otuz yılda giderek artış göstermiştir. İlk çalışmalar genellikle sınav kaygısını ölçme, betimleme ve onunla ilişkili değiş̧kenleri belirleme odağındayken (Albayrak-Kaymak, 1987; Öner, 1990; Başarır, 1990; Erktin ve Öner, 1990; Erözkan, 2004) günümüze yaklaştıkça önleme temelinde deneysel çalışmalar (Bozanoğlu, 2005; Koruklu, Öner ve Oktaylar, 2006; Karataş ve Tagay, 2019) artış göstermiştir. Ancak, sınav türünün çeşitlenmesi ve öğrencilerin giderek daha fazla sınavla baş etmek zorunda olması ilişkisel çalışmaların önemini koruyan bir faktördür. Ayrıca, sınav kaygısını azaltmada kullanılacak psikoeğitsel programların da diğer tüm psikoeğitim programlarında olduğu gibi kuramsal ve görgül bulguyla desteklenmesi gerekmektedir (Çivitci, 2019). Bilişsel Karışım Modeline göre (Cognitive Interference Model) yüksek düzeyde sınav kaygısı olan öğrenciler, sınav sırasında rekabet eden düşünceleri bastıramadıkları için büyük ölçüde yetersiz performans göstermektedir (Cassady ve Johnson, 2002). Bu modele göre sinav kaygısı daha çok bilişsel düzeyde ortaya çıkan bir durumdur. Bu kuramsal temeli test etmek ve sınav kaygısına yönelik yürütülecek deneysel çalışmalara görgül dayanak oluşturmak amacıyla bu araştırmada bilişsel ve duygusal düzenlemenin sınav kaygısına olan etkisinde psikolojik dayanıkl1lığın aracılık ettiğine yönelik hipotez modelin test edilmesi amaçlanmıştır.

\section{Yöntem}

Araştırmanın hipotez modelinde bilişsel ve duygusal düzenlemenin sınav kaygısına olan etkisinde psikolojik dayanıklılığın aracılık etkisi incelenmiştir. Bu amaç doğrultusunda nicel araştırma olan çalışma, ilişkisel tarama modeline dayanmaktadır.

\section{Araştırmanın Çalışma Grubu}

Araştırmanın evrenini 2017-2018 öğretim yılında Aydın Adnan Menderes Üniversitesinde öğrenim gören lisans öğrencileri oluşturmuştur. Araştırma kapsamında uygun örnekleme yöntemi ile $n=367$ ögrenciden araştırma verisi toplanmıştır. Bu katılımcı grubunun 252'si kadın $(\% 68,65), 115$ 'i ise erkektir (\%31,35). Katılımciların 98'i (\%26,70) birinci sinıf, 83'ü $(\% 22,60)$ ikinci sınıf, 85'i (\%23.20) üçüncü sınıf ve 101'i $(\% 27,50)$ dördüncü sınıf öğrencisidir. Katılımcıların yaş ortalaması 21 yaş 1 aydır. 


\section{Araştırmada Kullanılan Veri Toplama Araçları}

\section{Bilişsel ve Duygusal Düzenleme Ölçeği}

Ölçek sekiz maddeyle bilişsel düzenleme (dört madde) ve duygusal düzenleme (dört madde) olmak üzere iki alt boyuttan oluşmaktadır. Bilişsel ve Duygusal Düzenleme Ölçeği, Yeo ve Frederics (2011) tarafından geliştirilmiştir. Araştırmacılar, iki faktörlü yapıda araştırma verisi ve model arasında yeterli uyumun olduğuna ulaşmıştır. Bilişsel düzenleme için iç tutarlılığın .84, duygusal düzenleme içinse .81 olduğunu belirlemiştir. Ölçeğin Türkçe geçerlik ve güvenirlik çalışması Akın, Demirci, Çardak, Işık ve Yıldız (2012) tarafından yapılmıştır. Araştırmacılar yap1 geçerliliği için doğrulayıcı faktör analizinde iki faktörlü modelin özgün formla uyum gösterdiğini bulmuştur $\left(\chi^{2}=22,72\right.$, s.d. $=19$, RMSEA=.022, NFI= .99, CFI=1.00, IFI=1.00 GFI=.99, SRMR=.033). Ölçeğin Cronbach alfa iç tutarlılık güvenirlik katsayısını .70 olarak rapor etmiştir. Madde analizi için yapılan düzeltilmiş madde toplam korelasyonu .32 ile .65 arasında sıralandığına ulaşmıştır. Bu araştırmada ölçeğin bilişsel düzenleme boyutunun iç tutarlılık katsayısı .72, duygusal düzenleme boyutunun iç tutarlılık katsayısı .74 olarak hesaplanmıştır.

\section{Kısa Psikolojik Dayanıklılık Ölçeği}

Kısa Psikolojik Dayanıklılık Ölçeğini Smith, Dalen, Wiggins, Tooley, Christopher ve Bernard (2008), bireylerin stres kaynaklarıyla esneklik kaynakları arasında ilişkiyi incelerken, bu ilişskinin sağlık sonuçlarını yordayıp yordamadığını değerlendirmek için gerekli olan en az sayıda maddenin kullanılmasını amaçlayarak geliştirmiştir. Akın ve çalışma arkadaşları (2014) ölçeğin Türkçe'ye uyarlama çalışmasını yapmıştır. Araştırmacılar, bu doğrultuda ölçeğin geçerlik ve güvenirlik analizleri gerçekleştirmiştir. Ölçeğin yapı geçerliği için 255 üniversite öğrencisinden veri toplamış ve bu veriler üzerinde doğrulayıcı faktör analizi uygulamıştır. İlgili araştırmada özgün formun madde sayısının korunarak ölçeğin 6 madde olarak Türkçe'de doğrulandığı belirlenmiştir. Doğrulayıcı faktör analizi sonucunda elde edilen uyum indeksi değerlerinin özgün formdaki model ile benzerlik gösterdiği rapor edilmiştir $\left(\chi^{2}=6.44\right.$, s.d. $\left.=5, \mathrm{RMSEA}=.031, \mathrm{CFI}=.99, \mathrm{GFI}=.99, \mathrm{SRMR}=.028\right)$. Ölçeğin Cronbach alfa iç tutarlılık güvenirlik katsayısı .66 olarak, düzeltilmiş madde toplam korelasyonu .21 ile .51 arasında sıralandığı rapor edilmiştir. Doğan'ın (2015) .83 olarak belirlediği iç tutarlılık değeri, bu araştırmada .80 olarak belirlenmiştir.

\section{Westside Sınav Kaygısı Ölçeği}

Westside Sınav Kaygısı Ölçeği, Driscoll (2007) tarafindan öğrencilerin anksiyete bozukluğunu belirlemek ve sınav kaygısını azaltmaya yönelik eğitim programlarının etkililiğinin test edilmesi amacıyla geliştirilmiş̧ir. Bu ölçek on maddeden oluşmaktadır. Türkçeye üniversite öğrencileri için Totan ve Yavuz (2010) tarafından uyarlanmıştır. Totan ve Yavuz (2010) ölçekteki bir maddenin iki değişkeni ölçtügünü belirleyerek bu maddeyi iki farklı madde olarak Türkçeye çevirmiştir. Böylece ölçekteki toplam madde sayısı on bire çıkmıştır. Driscoll (2007), ölçeğin kapsam geçerliğini incelerken iç tutarlılığını ve yapı geçerliğini incelememiştir. Türkçe uyarlama çalışması yapan Totan ve Yavuz (2007) doğrulayıc faktör analiziyle veri ve model uyumunun yeterlilik gösterdiğini bulmuştur $\left(\chi^{2}=155,02\right.$, s.d. $=42$, RMSEA $=.045$, NFI $=.96, \mathrm{CFI}=.97$, IFI=.97 GFI=.93, RFI=.95, RMR=.046). Ölçeğin, Cronbach alfa iç tutarlılık katsayısını. 89 ve düzeltilmiş madde toplam korelasyonlarının .47.71 arasında sıralandığını rapor edilmiştir. Bu araştırmada ise ölçeğin iç tutarlık katsayısı .89 düzeyindedir.

\section{Kişisel Bilgi Formu}

Kişisel bilgi formu, araştırma katılımcılarının bir dizi kişisel özelliklerine ait sayı ve yüzdelerinin belirlemesi amacıyla kullanılmıştır. Bu formla katılımcıların cinsiyetlerine, üniversite de eğitim aldıkları sınıf düzeylerine ve yaşlarına ait bilgiler saptanmıştır. 


\section{Verilerin Toplanması, Analizlere Hazırlık ve Hipotez model}

Araştırma verileri, 2017-2018 eğitim öğretim yılının bahar döneminde toplanmıştır. Verilerin toplanması sırasında üniversite öğrencilerine araştırmanın amacı, veri formundaki soruları içtenlikle yanıtlamalarının önemi ve araştırma verilerinin toplu değerlendirileceği yönelik ölçme yönergeleri verilmiştir. Araştırmaya katılım konusunda onayı ve gönüllüğü olan bireyler araştırmada katılımcı olarak yer almıştır. Kayıp değer analizlerinde veride \%5’ten daha az kayıp veri olduğu belirlenmiştir. Parametrik testlerin varsayımları incelendiğinde araştırma verisinde normal dağılım ve doğrusallığın sağlandığı tespit edilmiştir. Bu işlemlerden sonra değişkenler arasındaki ikili ilişkiler Pearson Momentler Çarpımı korelasyon katsayılarıyla hesaplanmıştır. Anlamlı düzeyde ilişkinin varlığı belirlenince aşağıda anlatılan araştırmanın hipotez modeli yapısal eşitlik modellemesinde yol analizleriyle incelenmiştir.

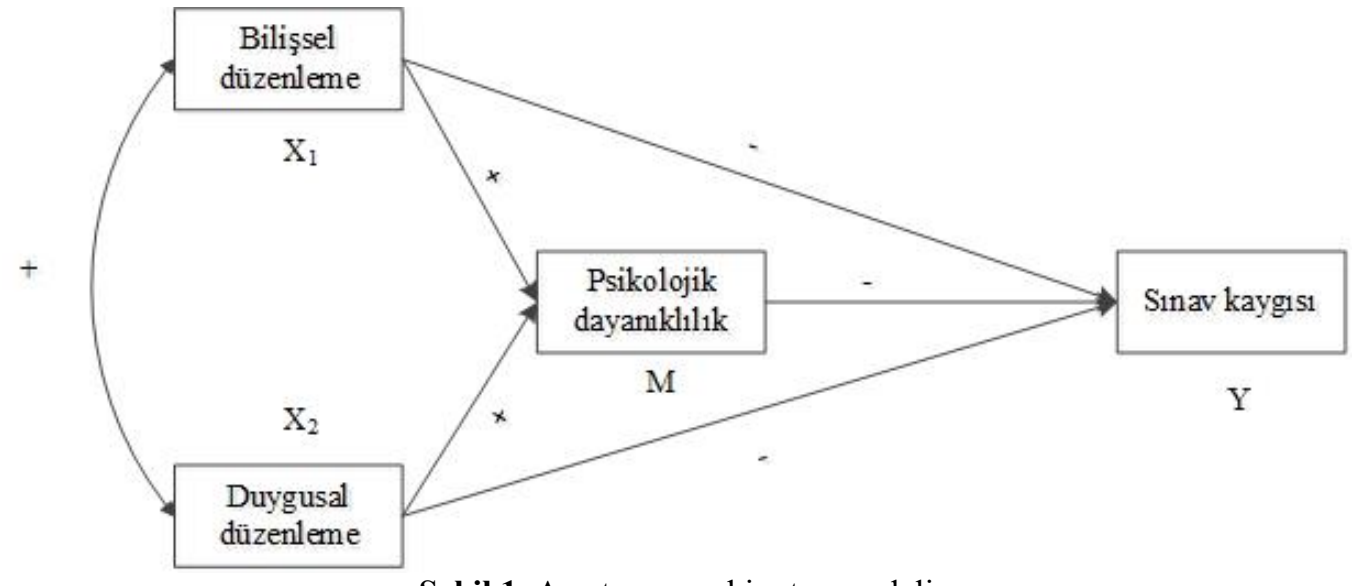

Şekil 1. Araştırmanın hipotez modeli

Araştırmanın hipotez modeline göre bilişsel ve duygusal düzenleme arasında pozitif yönde bir ilişki bulunmakta, her iki değişken psikolojik dayanıklılığı pozitif yönde ve sınav kaygısını negatif yönde doğrudan etkilemektedir. Ayrıca bilişsel ve duygusal düzenleme psikolojik dayanıklılık üzerinden de negatif yönde sınav kaygısını dolaylı olarak etkilemektedir. Araştırmanın yordayıcı değişkenleri (X) bilişsel ve duygusal düzenleme, aracı değişkeni (M) psikolojik dayanıklılık, yordanan değişkeni ise (Y) sınav kaygısıdır. Araştırmanın analizlerinde SPSS ve AMOS paket programları kullanılmıştır.

\section{Bulgular}

Araştırmada bilişsel düzenleme, duygusal düzenleme, psikolojik dayanıklılık ve sınav kaygısı değişkenlerinde, çok değişkenli istatistikler ve parametrik teknikler için gerekli olan varsayımsal kriterler incelenmiştir. Bu incelemeler sonrasında araştırma değişkenleri arasındaki ikili ilişkiler Pearson momentler çarpımı korelasyon katsayılarıyla belirlenmiştir. $\mathrm{Bu}$ bulgulara ait elde edilen sonuçlar aşağıda yer almaktadır.

Tablo 1. Araştırma Değişkenleri Arasındaki İkili İlişsilerle Betimsel İstatistik Bulguları

\begin{tabular}{|c|c|c|c|c|c|c|c|}
\hline Değişkenler & $\begin{array}{c}\text { Bilişsel } \\
\text { düzenleme }\end{array}$ & $\begin{array}{c}\text { Duygusal } \\
\text { Düzenleme }\end{array}$ & $\begin{array}{c}\text { Psikolojik } \\
\text { dayanıklılık }\end{array}$ & $\overline{\mathbf{x}}$ & s.d. & Çarpıklık & Basıklık \\
\hline $\begin{array}{l}\text { Bilişsel } \\
\text { düzenleme }\end{array}$ & & & & 15,62 & 3,17 &,- 459 &,- 254 \\
\hline $\begin{array}{l}\text { Duygusal } \\
\text { Düzenleme }\end{array}$ & $.25 *$ & & & 11,93 & 3,04 & ,052 & ,281 \\
\hline $\begin{array}{l}\text { Psikolojik } \\
\text { dayanıklılık }\end{array}$ & $.18^{*}$ & $.38^{*}$ & & 18,24 & 4,87 &,- 191 &,- 074 \\
\hline Sinav kaygisı & $-.14 *$ & $-.18 *$ & $-.41 *$ & 30,85 & 8,61 & ,263 &,- 212 \\
\hline
\end{tabular}


Araştırma değişkenlerinde basıklık ve çarpıklık katsayılarının \pm 1 arasında kaldığ 1 ve Kolmogorov Smirnov istatistiklerinde $p$ değerinin istatistiksel olarak anlamsız olduğu $(p \leq 0.05)$ belirlenmiştir. Pearson momentler çarpımı korelasyon analizlerinde elde edilen sonuçlara göre bilişsel düzenleme ve duygusal düzenleme arasında pozitif yönde $\left(r^{2}=.06\right)$ bir ilişki bulunmaktadır. Bilişsel düzenlemenin psikolojik dayanıklılıkla arasında pozitif yönde $\left(r^{2}=.03\right)$ ilişki bulunurken, sınav kaygısıyla arasında negatif yönde $\left(r^{2}=.02\right)$ ilişki bulunmaktadır. Duygusal düzenlemede psikolojik dayanıklılıkla pozitif yönde $\left(r^{2}=.14\right)$, sınav kaygısıyla negatif yönde $\left(r^{2}=.03\right)$ ilişkilidir. Ayrıca, sınav kaygısı ve psikolojik dayanıklılık arasında negatif yönde $\left(r^{2}=.17\right)$ bir ilişki bulunmaktadır. Korelasyon analizlerinde hipotez modeli test etmek için yeterli ikili ilişkiler belirlenmiş̧ir. Ayrıca bu sonuçlar çoklu bağıntı problemi olmadığını da göstermektedir. Bunun üzerine araştırmanın hipotez modelinin yapısal eşitlik modelinde yol analiziyle incelenmesine geçilmiştir.

Bilişsel ve duygusal düzenlemedeki yetersizliklerin sınav kaygısına olan etkisinin doğrudan mı, yoksa psikolojik dayanıklılık üzerinden dolaylı mı olduğu incelenmiştir. Öncelikle bilişsel ve duygusal düzenlemenin sınav kaygısı üzerindeki doğrudan etkisinin düzeyi ve yönü hesaplanmıştır. Yapısal eşitlik modelinde yol analizi sonucunda elde edilen sonuçlara göre bilişsel düzenleme ve duygusal düzenleme arasında pozitif yönde (.42) ilişki bulunmaktadır. Bilişsel düzenleme (-.29) ve duygusal düzenleme de (-.20) negatif yönde sınav kaygısını etkilemektedir. Bağımsız değişkenlerin birlikte bağımlı değişken üzerindeki doğrudan etkisinin anlamlılığı Bootstrap yöntemiyle incelenmiştir. Sonuçlara göre bilişsel düzenleme (Bootstrap tahmini=-.72, s.h.=.26, $p=.005, \% 95$ Güven aralığı=1.137/-.282) ve duygusal düzenlemenin (Bootstrap tahmini=-.74, s.h.=.15, $p=.002, \% 95$ Güven aralığ $1=-.966 /-.471)$ sınav kaygısı üzerindeki doğrudan etkileri anlamlıdır. Bu işlem adımı sonrasında aracı değişken psikolojik dayanıklılık modele eklenerek analiz tekrarlanmıştır.

Tablo 2. Bilişsel ve Duygusal Düzenlemenin Sınav Kaygısına Olan Etkisinde Psikolojik Dayanıklılığın Aracılığına Ait Standartlaştırılmış Regresyon Yükleri

\begin{tabular}{lcccc}
\hline Yol analizinin yönü & Tahmin & s.h. & $t$ & $p$ \\
\hline Psikolojik dayanıklılık $\rightarrow$ Bilişsel düzenleme &, 26 &, 06 & 5,42 &, $001^{*}$ \\
Psikolojik dayanıklılık $\rightarrow$ Duygusal düzenleme &, 36 &, 08 & 7,48 &, $001^{*}$ \\
Sinav kaygıs1 $\rightarrow$ Bilişsel düzenleme &,- 16 &, 13 & 3,30 &, $001^{*}$ \\
Sinav kaygısı $\rightarrow$ Psikolojik dayanıklılık &,- 47 &, 11 & 9,22 &, $001^{*}$ \\
Sinav kaygısı $\rightarrow$ Duygusal düzenleme &,- 03 &, 19 &, 55 &, 585 \\
\hline
\end{tabular}

Bilişsel düzenleme ve duygusal düzenlemenin sınav kaygısına olan etkisinde psikolojik dayanıklılığın aracılık etkisi incelendiğinde psikolojik dayanıklılığın modele eklenmesiyle bilişsel düzenleme ve sınav kaygısı arasındaki yol değerinin .17'e, duygusal düzenleme ve sınav kaygısı arasındaki yol değerinin ise .07'e düştüğü belirlenmiştir. Aracı değişken psikolojik dayanıklılığın modele eklenmesiyle bilişsel düzenleme ve sınav kaygısı arasındaki yol istatistiksel olarak anlamlılığını korurken, duygusal düzenleme ve sınav kaygısı arasındaki yol istatistiksel olarak anlamlılığını kaybetmiştir. Araştırmanın hipotez modeline ait sonuçları şekil 2'de gösterilmiştir.

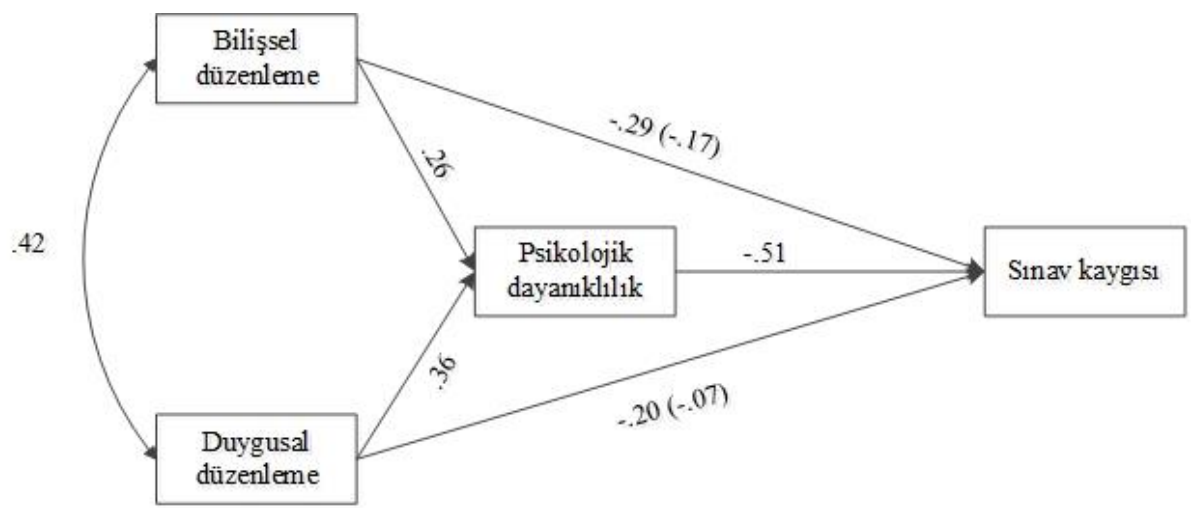

Şekil 2. Bilişsel ve duygusal düzenlemenin sınav kaygısına olan etkisinde psikolojik dayanıklılığın aracılığına yönelik model şeması 
Aracı değişkenin modele eklenmesi sonrasında bilişsel düzenleme ve duygusal düzenleme arasında orta düzeyde bir ilişki bulunmuştur. Bilişsel düzenleme psikolojik dayanıklılıkla pozitif yönde sınav kaygısıyla ise negatif yönde yola sahiptir. Benzer olarak duygusal düzenlemede psikolojik dayanıklılıkla pozitif yönde sınav kaygısıyla negatif yönde yollara sahiptir. Psikolojik dayanıklılık ve sınav kaygısı arasındaki yol ise negatif yöndedir. Sonuçlara göre bilişsel düzenleme ve sınav kaygısı arasında psikolojik dayanıklılık kısmi aracı değişken (Bootstrap tahmini=-.32, s.h.=.08, $p=.001, \% 95$ Güven aralığı=-.48/-.20), duygusal düzenleme ve sınav kaygısı arasında ise tam aracı değişkendir (Bootstrap tahmini=-.62, s.h.=.12, $p=.001, \% 95$ Güven aralığ $1=-.82 /-.44$ ).

\section{Tartışma ve Sonuç}

$\mathrm{Bu}$ araştırmada bilişsel düzenleme ve duygusal düzenlemenin sınav kaygısı üzerindeki doğrudan etkileri ve psikolojik dayanıklılık üzerinden dolaylı etkileri incelenmiştir. Ayrıca, bilişsel ve duygusal düzenlemenin sınav kaygısını azaltmadaki etkilerinde psikolojik dayanıklılığının aracı rolünün belirlenmesi hedeflenmiştir. Araştırmanın kavramsal modelinde yer alan hipotezleri test etme amacıyla Baron ve Kenny'in (1986) önerdiği yaklaşım kullanılmıştır. Ancak, Cheng ve Lau'nun (2008) AMOS programında Sobel testi yerine Bootstrap yaklaşımını kullanmanın daha güvenilir olduğunu önerisi dikkate alınarak Sobel testi yerine Bootstrap yaklaşımı kullanılmış ve beş bin alt örneklemde güven aralıkları hesaplanmıştır. Araştırmanın ilk hipotez modelinde yüksek düzeydeki bilişsel ve duygusal düzenlemenin düşük düzeyde sınav kaygısı yaşamayı doğrudan etkileme düzeyleri ve istatistiksel anlamlılığ incelenmiştir. Sonraki hipotezlerde ise bilişsel ve duygusal düzenlemenin sınav kaygısı üzerindeki etkisinde psikolojik dayanıklılığın aracı etkisine yönelik yapısal model test edilmiştir.

Araştırma bulgularına göre bilişsel düzenleme ile duygusal düzenleme ilişkilidir. Bilişsel ve duygusal düzenleme psikolojik dayanıklılığı pozitif yönde etkilerken sınav kaygısı üzerinde negatif etkiye sahiptir. Diğer bir ifadeyle bilişsel ve duygusal düzenleme düzeyleri yüksek olan bireylerin psikolojik dayanıklılıklarının da yüksek olduğu, sınav kaygılarının ise düşük olduğu belirlenmiştir. Alanyazın incelendiğinde Jung ve Kang (2014) yaptıkları araştırmada bilişsel-duygusal düzenleme stratejilerini kullanan bireylerin daha düşük sınav kaygısı yaşadıklarını, bilişsel-duygu düzenleme stratejilerini daha az kullanan bireylerin ise daha yüksek sınav kaygısı yaşadıklarını bulmuştur. Abolghasemi, Beygi ve Narimani'nin (2012) çalışmalarında bilişsel davranış stratejileri ve duygularla başa çıkabilme becerileri eğitiminin, bireylerin sınav kaygısını azaltmada ve psikoloji sağlığının iyileştirilmesinde etkili olduğunu yönündedir. Alanyazındaki bu çalışmalar, araştırmanın hipotez modelindeki yüksek bilişsel ve duygusal düzenlemenin düşük sınav kaygısı yaşamayı doğrudan etkilediği bulgusunu destekler niteliktedir.

Sınav kaygısının bilişsel düzenleme, duygusal düzenleme ve psikolojik dayanıklılıkla olumsuz yönde ilişkili olduğu belirlenmiştir. Sınav kaygısının psikolojik dayanıklılıkla ilişkisinde orta, bilişsel ve duygusal düzenlemeyle olan ilişkisinde ise düşük düzeyde kabul edilebilecek etki büyüklükleri hesaplanmıştır. Kavramsal modelin ilk aşaması, bilişsel ve duygusal düzenlemenin sınav kaygısı üzerinde negatif yönde etkisinin olduğunu göstermektedir. Buna göre bilişsel ve duygusal düzenlemesi yüksek olan öğrenciler daha düşük düzeyde sınav kaygısı yaşamaktadırlar. Bilişsel düzenlemenin sınav kaygısı üzerindeki azaltıcı etkisi duygusal düzenlemeye göre daha yüksektir. Sınav kaygısının bilişsel ve duygusal kaynaklı bir faktör olduğu daha önceki çalışmalarda incelenmiştir (Cassady ve Johnson, 2002). Bilişsel davranışçı kuramı dayanak alan Sapp (1999) bilişsel bileşenlerin kaygıyı, davranışsal bileşenlerin ise duygusallığı kavramsallaştırdığını savunmaktadır. Bu dayanak aracılık testi sonuçlarıyla örtüşmektedir. Sınav kaygısının duygusal düzenlemeden çok bilişsel düzenlemeyle daha ilişkili bir faktör olduğu söylenebilir. Diğer bir ifadeyle sınav kaygısının ortaya çıkmasını arttıran değişkenler olarak öğrencilerin düşüncelerini kontrol edemedikleri bilişsel düzenlemedeki sorunları sınav kaygısı üzerinde duygu kontrolünden daha fazla etkiye sahiptir.

Psikolojik dayanıklılığın sınav kaygısı üzerindeki etkisi incelendiğinde negatif yönde bir etki bulunmuştur. Buradan psikolojik dayanıklılığın artmasının sınav kaygısını düşürdüğü sonucuna varılmaktadır. Alanyazın incelendiğinde Yılmazer'in (2017) öğretmen adayları ile yaptığı çalışmada 
sınav kaygısı düzeyleri arttıkça psikolojik dayanıklılık ölçeğinden alınan puanların azalmakta olduğunu belirlemiştir. Bu çalışma elde edilen bulguyu destekler niteliktedir. Sonuçlara göre bilişsel düzenleme ve sınav kaygısı arasındaki ilişkide psikolojik dayanıklılık kısmi aracıdır. Diğer bir ifadeyle, bilişsel düzenleme düzeyleri düşük olan bireylerin sahip oldukları yüksek sınav kaygısı düzeyleri onların psikolojik dayanıklılık düzeylerinden kısmen etkilenmektedir. Duygusal düzenleme ve sınav kaygısı arasındaki ilişki de ise psikolojik dayanıklılık tam aracıdır. Diğer bir ifadeyle, bireylerin psikolojik dayanıklılığının yüksek olması onları duygusal düzenleme eksikliğinin neden olacağı sınav kaygısından korumaktadır. Bireylerin duygusal düzenlemedeki eksiklikleri onların sınav kaygısını azalmakta ancak bu etki psikolojik dayanıklılıklarının yüksek olması durumunda anlamını kaybetmektedir. Bu bulgu Sapp (1999) ile Cassady ve Johnson'ın (2002) sinav kaygısı üzerindeki bilişsel düzenlemeye yönelik açıklamasıyla örtüşmektedir.

Sonuç olarak bilişsel ve duygusal düzenlemesi yüksek olan bireylerin psikolojik dayanıklılı̆̆ın yüksek olduğu, bunun da sınav kaygısı üzerinde bireylerde koruyucu bir faktör oluşturduğu düşünülmektedir. Bunun yanı sıra sınav kaygısını azaltmada bilişsel ya da duygusal düzenlemeden daha çok psikolojik dayanıklılı̆̆ın etkisi olduğu görülmüştür. Psikolojik dayanıklılık arttıkça sınav kaygısının azalma düzeyi bilişsel ya da duygusal düzenlemenin artışına göre daha etkilidir. Bu bulgular dikkate alındığında sınav kaygısı yaşayan bireylerde psikolojik dayanıklılığın desteklenmesi sınav kaygısı üzerinde olumlu etki yaratacaktır. Psikolojik dayanıklılık faktörleri incelendiğinde; zekâ, akademik başarı, iç kontrol odağı, benlik saygısı ve öz yeterlik, iyimserlik ve umut, özerlik, kişisel farkındalık, kendini kabul olduğu görülmektedir (Gizir, 2016). Bu bilgiden yola çıkarak psikolojik dayanıklılığın arttırılmasında, bu faktörlerin ele alınması çalışmaların etki düzeyini arttırılabilir. Bilişsel ve duygusal düzenlemenin ise hem psikolojik dayanıklılığa hem de sınav kaygısına etkisi olacağı söylenebilir. Duygusal düzenleme becerisini geliştirmek için duyguları kabul etme, duyguyla başa çıkmaya dönük strateji (Eldoğan ve Barışkın, 2014); bilişsel düzenlemede kabul ve olumlu yeniden odaklanma stratejileri geliştirme (Temizel Ataman ve Dağ, 2014) gibi içeriğin dikkate alınması sınav kaygısının azalmasında etkili olabilir. Sınav kaygısı ile baş etmede bu temaları içeren bilişsel ve duygusal düzenleme eğitim programlarının geliştirilmesi önerilebilir. Bu çalışmalarda bilişsel düzenlemeye daha fazla odaklanılması programların etkililiğine katkı sağlayabilir. Bilişsel ve duygusal düzenlemenin sınav kaygısı üzerindeki etkisinde psikolojik dayanaklılığın aracılığını araştıran çalışma alan yazında bulunmamaktadır. Çalışma bu yönüyle alan yazına katkı sağlamaktadır. Ancak, çalışmanın bazı sınırlılıkları olduğu söylenebilir. Bunlardan ilki araştırma katılımcılarının aynı üniversitede okuyan öğrencilerden olmasıdır. Araştırma sonuçları aynı veya benzer gruplarda geçerliğini koruyabilir. Bu sebeple farklı yaş ve eğitim seviyelerinde hipotez modelin incelenmesi önerilebilir. Özellikle ergenlik dönemine ait araştırmalar sınav kaygısının doğasını anlamada ve önleme hizmetlerine yönelik psikolojik danışma ve rehberlik faaliyetlerinin geliştirilmesinde etkili olabilir. Diğer bir sınırlılık ise sınav kaygısının tek bir kuramsal çerçevede ele alınmasıdır. Sınav kaygısını farklı kuramsal dayanaklarla tanımlayan ölçme araçlarıyla kavramsal model test edilebilir. Ayrıca hipotez model sosyoekonomik düzey, cinsiyet, yaş ve eğitim alınan bölüm gibi bir dizi sosyokültürel değişkenle de sınırlandırılarak test edilebilir.

\section{Kaynakça}

Abolghasemi, A., Beygi, P., \& Narimani, M. (2012). Comparison the efficacy of trainings of cognitive-behavior and emotion regulation skills on self-efficacy and academic adjustment of students with test anxiety. Quarterly Educational Psychology, 22(7), 2142.

Akın, A., Demirci, İ., Çardak, M., Işık, Y., \& Yııldız, E. (2012). The validity and reliability of the Turkish version of the Cognitive and Affective Regulation Scale. Paper presented at the International Interdisciplinary Social Inquiry Conference- IISIC, Haziran, 1721, Bursa, Turkey. 
Akın, A., Sahranç, Ü., Turan, M. E., Akın, Ü., Kaya, M., \& Ercengiz, M. (2014, Haziran). Kısa Psikolojik Dayanıklılık Ölçeği Türkçe Formu'nun geçerlik ve güvenirliği. III. Sakarya Eğitim Araştırmaları Kongresi, 12 Haziran, Sakarya.

Albayrak-Kaymak, D. (1987). Sınav Kaygısı Envanterinin Türkçe formunun oluşturulması ve güvenirliği. Psikoloji Dergisi, 6(21), 55-62.

Aydın, G. (2017). Assessing a model of cognitive test anxiety: The role of rumination, selfforgiveness, perfectionism cognitions and cognitive defusion through the indirect effect of psychological flexibility. (Yayımlanmamış doktora tezi). Orta Doğu Teknik Üniversitesi, Sosyal Bilimler Enstitüsü, Ankara.

Aydoğmuş, E. (2016). Öğrencilerin alglladıkları ögretmen tutumu ile sınav kaygısı arasındaki ilişki ve bir araştırma. (Yayımlanmamış yüksek lisans tezi). Yeditepe Üniversitesi, Eğitim Bilimleri Enstitüsü, İstanbul.

Baltaş, A. (2002). Öğrenmede ve sınavlarda üstün başarı. İstanbul: Remzi Kitabevi Yayınları. Baron, R.M., \& Kenny, D.A. (1986). The moderator-mediator variable distinction in social psychological research: Conceptual, strategic, and statistical considerations. Journal of Personality and Social Psychology, 51, 1173-1182.

Başarır, D. (1990). Ortaokul son sını ögrencilerinde sınav kaygısı, durumluk kaygl, akademik başarı ve sınav başarısı arasındaki ilişkiler. (Yayınlanmamış yüksek lisans tezi). Hacettepe Üniversitesi, Sosyal Bilimleri Enstitüsü, Ankara.

Bozanoğlu, İ. (2005). Bilişsel davranışçı yaklaşıma dayalı grup rehberliğinin güdülenme, benlik saygısı, başarı ve sınav kaygısı düzeylerine etkisi. Ankara Üniversitesi Ĕ̈itim Bilimleri Fakültesi Dergisi, 38(1), 17-42.

Bükülmez, E. (2015). İlköğretim 8.sınıf ögrrencilerinde sınav kaygısı ve ders çalışma yaklaşımları arasındaki ilişkisi. (Yayımlanmamış yüksek lisans tezi). Nişantaşı Üniversitesi, Sosyal Bilimler Enstitüsü, İstanbul.

Cassady, J.C., \& Johnson, R.E. (2002). Cognitive test anxiety and academic performance. Contemporary Educational Psychology, 27(2), 270-295.

Cheung, G.W., \& Lau, R.S. (2008). Testing mediation and suppression effects of latent variables: Bootstrapping with structural equation models. Organizational Research Methods, 11(2), 296-325.

Çivitci, A. (2019). Grup psikoeğitimi (2. bask1). Ankara: Pegem Akademi.

Demir, M. (2015). Okul tükenmişliğinin yordanmasında sınav kaygısl ve akademik başarının etkisi. Yayımlanmamış yüksek lisans tezi, Atatürk Üniversitesi, Eğitim Bilimleri Enstitüsü, Erzurum.

Driscoll, R. (2007). Westside Test Anxiety Scale validation. ERIC Digest, ED495968.

Doğan, T. (2015). Kısa Psikolojik Sağlamlık Ölçeği'nin Türkçe uyarlanması: Geçerlik ve güvenirlik çalışması. The Journal of Happiness \& Well-Being, 3(1), 93-102.

Eker, O. (2016). Ortaokul öğrencilerinin yaşadı̆̆ı sınav kaygısının nedenleri ve anne- baba tutumlarının sinav kaygısına etkisi: Merzifon örneği. (Yayımlanmamış yüksek lisans tezi). Nişantaşı Üniversitesi, Sosyal Bilimler Enstitüsü, İstanbul.

Eldoğan, D. \& Barışkın, E. (2014). Erken dönem uyumsuz şema alanları ve sosyal fobi belirtileri: Duygu düzenleme güçlüğünün aracı rolü var mı? Türk Psikoloji Dergisi, 29(74), 108.

Ergene, T. (2011). The relationships among test anxiety, study habits, achievement, motivation, and academic performance among Turkish high school students. Eğitim ve Bilim, 36(160), 320-330.

Erktin, E., \& Öner, N. (1990). Matematik kaygısı: Başarı, sınav kaygısı ve meslek seçimi ile ilişkisi. IV. Ulusal Psikoloji Kongresi. İstanbul Üniversitesi Edebiyat Fakültesi, Istanbul, 5-7. 
Erözkan, A. (2004). Üniversite öğrencilerinin sınav kaygısı ve başa çıkma davranışları. Muğla Üniversitesi Sosyal ve Beşerî Bilimler Araştırmaları Dergisi, 12(1), 13-38.

Gizir, C.A. (2016). Psikolojik sağlamlık, risk faktörleri ve koruyucu faktörler üzerine bir derleme çalışmas1. Türk Psikolojik Danışma ve Rehberlik Dergisi, 3(28), 113-128.

Güler, D., \& Çakır, G. (2016). Lise son sınıf öğrencilerinin sınav kaygısını yordayan değişkenlerin incelenmesi. Türk Psikolojik Danışma ve Rehberlik Dergisi, 4(39), 8294.

Hanımoğlu, E. (2010). Seviye belirleme sinavina girecek olan ilköğretim ikinci kademe ögrencilerinde sinav kaygısı, mükemmeliyetçilik ve anne-baba tutumu arasındaki ilişkinin incelenmesi. Yayımlanmamış yüksek lisans tezi, Çukurova Üniversitesi, Sosyal Bilimler Enstitüsü, Adana.

Jung, A., \& Kang, M.J. (2014). The effects of perfectionism and cognitive-emotion regulation strategies on test anxiety. Korean Journal of Child Studies, 35(1), 61-76.

Kahramanoğlu, H. (2018). Üst biliş ve pozitif psikolojik sermayenin sınav kaygısı ile ilişkisi. (Yayımlanmamış yükssek lisans tezi). Haliç Üniversitesi, Sosyal Bilimler Enstitüsü, İstanbul.

Karataş, Z., \& Tagay, Ö. (2019). Yaratıcı drama temelli sınav kaygısı ile baş etme çalışmasının özel/üstün yetenekli öğrencilerin sınav kaygısına etkisi. Afyon Kocatepe Üniversitesi Sosyal Bilimler Dergisi, 21(1), 97-107.

Kartalkıyı, İ. (2016). Ortaokul düzeyindeki çocukların ebeveynlerinin tutum biçimlerinin sınav kaygısı üzerine etkisinin araştırılması. Yayımlanmamış yüksek lisans tezi, Üsküdar Üniversitesi, Sosyal Bilimler Enstitüsü, İstanbul.

Kavakcı, Ö., Güler, A. S., \& Çetinkaya, S. (2011). Sınav kaygısı ve ilişkili psikiyatrik belirtiler. Klinik Psikiyatri, 14(1), 7-16.

Koç, İ. Y. (2014). KPSS'ye hazırlanan öğretmen adaylarının öğrenme stilleri ile sınav kaygısı arasındaki iliş̧kinin incelenmesi. (Yayımlanmamış yüksek lisans tezi). Yeditepe Üniversitesi, Sosyal Bilimler Enstitüsü, İstanbul.

Koruklu, N.Ö., Öner, H., \& Oktaylar, H.C. (2006). Sınav kaygısı ile başa çıkma programının sınav kaygısına etkisine yönelik deneysel bir çalışma. Dokuz Eylül Üniversitesi Buca Ĕ̈itim Fakültesi Dergisi, 19, 5-11.

Kring, A.M., Johnson, S.L., Davidson, G., \& Neale, J. (2015). Anormal psikoloji (Çev. İ. Dağ). Ankara: Türk Psikologlar Derneği Yayını.

Kurt, İ. (2011). Sınav kaygısını aşmanın yolları. İstanbul: Bizim Kitaplar.

Peters Mayer, D. (2008). Overcoming school anxiety. New York, NY: AMACOM.

Plotnik, R. (2009). Psikolojiye giriş (Çev. T. Geniş). İstanbul: Kaknüs yayınları.

Ormrod, J. E. (2015). Öğrenme psikolojisi (Çev. Ed. M. Baloğlu). Ankara: Nobel Yayınları.

Öner, N. (1990). Sinav kaygısı envanteri el kitabı. İstanbul: Yöret Yayınları.

Sapp, M. (1999). Test anxiety. Applied research, assessment, and treatment interventions (2. Bask1). Oxford, OX: University of America Inc.

Serim, S. (2016). Sınav kaygısı ile geleceğe yönelik umut beklentisi arasındaki ilişki: 17-18 yaş arası Ístanbul lise son sınıf öğrencileri üzerine bir araştırma. Yayımlanmamış yüksek lisans tezi, Beykent Üniversitesi, Sosyal Bilimler Enstitüsü, İstanbul.

Smith, B.W., Dalen, J., Wiggins, K., Tooley, E., Christopher, P., \& Bernard, J. (2008). The Brief Resilience Scale: Assessing the ability to bounce back. International Journal of Behavioral Medicine, 15(3), 194-200.

Temizel Ataman, E., \& Dağ, İ. (2014). Stres veren yaşam olayları, bilişsel duygu düzenleme stratejileri, depresif belirtiler ve kaygı düzeyi arasındaki ilişkiler. Klinik Psikiyatri Dergisi, 17(1), 7-17. 
Totan, T., \& Yavuz, Y. (2009). Westside Sınav Kaygısı Ölçeğinin Türkçe formunun geçerlik ve güvenirlik çalışması. Mehmet Akif Ersoy Üniversitesi Eğitim Fakültesi Dergisi, 9(17), 95-109.

Turan-Başoğlu, S. (2007). Sınav kaygısı ile özgüven arasındaki ilişkinin erinlik döneminde incelenmesi. Yayımlanmamış yüksek lisans tezi, Maltepe Üniversitesi, Sosyal Bilimler Enstitüsü, İstanbul.

Ürgüp, B. (2017). Ebeveynle gerçekleştirilen bağlanma stilinin sınav kaygısı üzerindeki yordayıcı etkisi. Yayımlanmamış yüksek lisans tezi, Üsküdar Üniversitesi, Sosyal Bilimler Enstitüsü, İstanbul.

Yeo G.B., \& Frederiks E.R. (2011). Cognitive and affective regulation: Scale validation and nomological network analysis. Applied Psychology: An International Review, 60(4), $546-575$.

Y1lmazer, F. (2017). Kamu Personeli Seçme Sinavina (KPSS) hazırlanan öğretmen adaylarının sınav kaygısına bağll olarak tükenmişlik düzeyi ve psikolojik dayanıklılıkları. Yayımlanmamış yüksek lisans tezi, Üsküdar Üniversitesi, Sosyal Bilimler Enstitüsü, İstanbul.

Zeidner, M. (1998). Test anxiety. The state of the art. New York, NY: Kluwer Academic Publishers. 